Canadian Journal of Higher Education

Revue canadienne d'enseignement supérieur

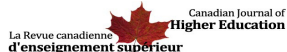

\title{
Book review of "An Online Doctorate for Researching Professionals: Program Design, Implementation, and Evaluation"
}

\section{Cindy Anne Ives}

Volume 48, Number 3, 2018

URI: https://id.erudit.org/iderudit/1057136ar

DOI: https://doi.org/10.7202/1057136ar

See table of contents

Publisher(s)

Canadian Society for the Study of Higher Education

ISSN

2293-6602 (digital)

Explore this journal

Cite this review

Ives, C. (2018). Review of [Book review of "An Online Doctorate for Researching Professionals: Program Design, Implementation, and Evaluation"]. Canadian Journal of Higher Education / Revue canadienne d'enseignement supérieur, 48(3), 185-187. https://doi.org/10.7202/1057136ar 


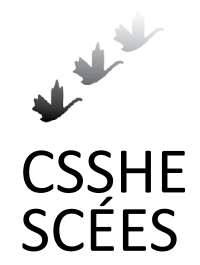

Canadian Journal of Higher Education Revue canadienne d'enseignement supérieur

Volume 48, No. 3, 2018, pages $185-187$

\title{
Book Review / Compte rendu
}

\author{
Kumar, Swapna and Dawson, Kara (2018). An Online Doctorate for Re- \\ searching Professionals: Program Design, Implementation, and Evalu- \\ ation. Edmonton AB: Athabasca University Press. Pages: 214. Price: 39.95 \\ CAD (paper).
}

Reviewed by Cindy Ives, Professor, Distance Education, Athabasca University

An Online Doctorate for Researching Professionals describes the design, implementation and early evaluation of an online EdD in Educational Technology (EdD ETEC) at the University of Florida. The authors and their colleagues developed the program in response to the needs of working professionals whose aspirations for further education and applied research skills, combined with continuing full-time employment, were not met by traditional PhD programs in Education. Kumar and Dawson, faculty members in the program, recount the experiences of designers, instructors, evaluators and students from the program's inception through three cohorts of students enrolled (and 56 graduates) from 2008 to 2014. They offer, through their reflections and analysis, a model of an online terminal degree for those interested in developing rigorous, quality programs for researching professionals, in any discipline. Their book provides an evidence-based response to an emerging international trend: the growth of new professional doctorates.

Divided into three parts, the book reflects the essential stages of program development: design, implementation and evaluation. Most chapters include examples of assignments, student research projects, student feedback and/or instructor reactions as evidence of success and lessons learned. A concluding section, Further Considerations, offers specific advice for academics considering the development of online professional doctoral programs. The book ends with a list of seminal references on distance and online education, program development, graduate education, learning theories, instructional philosophies, curriculum design principles, student support, quality frameworks, and educational evaluation. There are also scholarly articles by the University of Florida team detailing research results and other elements of the EdD ETEC program in the years before the publication of this book.

Part I focuses on the Theoretical Foundations and Design of the online professional doctorate, and includes chapters on the context for and grounding of the degree, and on the design of the curriculum. Here, the authors describe the benefits of distance educa- 
tion and claim that online delivery can address the increasing worldwide demand for professional doctorates serving researchers working in non-academic environments or for those who are unable to attend on-campus courses. They situate the EdD ETEC program design in theories of andragogy, transformative learning, and situated (workplace) learning, building on lived and documented educational practices that have shown success in both on-campus and online doctoral experiences. A significant goal of the professional doctorate, they assert, is the full integration of theory, research and practice through fostering scholarly and research competencies that inform practical problems embedded in interdisciplinary professional contexts. This first section illustrates how purposeful program design is essential to ensuring clear goals, relevant and aligned activities, available resources, engaged stakeholders and successful students.

Part II describes the Implementation of the program in chapters on building online communities, fostering scholarly thinking, dissertations, and online mentoring. The authors begin by explaining the essential design principles of the enacted community of inquiry (CoI) model (Garrison, Anderson \& Archer, 2000) they adopted to support students' sense of belonging to their doctoral program. To ensure persistence, support success and address expected transactional distance (Moore, 1993), the EdD ETEC prioritizes dialogue by offering multiple avenues for synchronous and asynchronous communication. The program integrates purposefully designed interactive learning activities throughout the courses, candidacy and dissertation stages of study to enhance teaching, social, and cognitive presences. The authors describe assignments and activities in enough detail to show their alignment and support for student scholarly development over time. In particular, they emphasize online faculty presence, given the doctoral requirement for models of scholarly "habits of mind" (p.76); faculty consciously inspire trust, encourage personal and professional learning, and lead by example in the expert use of technology and research methods. The program designers adapted the CoI framework to also incorporate learning presence (Shea \& Bidjerano, 2010), prescribing active learner engagement through compulsory, structured coursework that scaffolds learning but fades over time as students take over individual and group responsibility for their scholarship. The chapters on online dissertations and mentoring further highlight the critical nature of pro-active faculty support and are worth reviewing for the specific advice they offer to first-time online dissertation supervisors. These sections will also be of interest to those rethinking the dissertation in the context of more traditional doctoral programs (CAGS, 2018).

There is some repetition in Part II, the largest section of the book, which is understandable since the same program design approaches contribute to multiple instructional goals. While slightly irritating perhaps to those already familiar with the learning theories and instructional principles applied in this case, the overall effect is a demonstration of how an intentional, theory-based program development approach can be successful. Part III, which concentrates on Ensuring and Evaluating Quality, contains chapters on supporting and maintaining quality and identifying impact, illustrating the nature of the success claimed. In this section, the authors offer evidence that changes made in second and third offerings based on systematic, formative and summative assessment from multiple perspectives contributed to improved student learning, performance and satisfaction and a more coherent program, as well as to a process of continual improvement. They describe their use of program-integrated evaluation instruments, such as surveys, questionnaires, 
focus groups, semi-structured interviews and interaction analyses, for ongoing quality assurance at course, program, and institutional levels. They advise measuring impact holistically: for individuals, across the stages of coursework, candidacy, enculturation and dissertation; for graduates' work organizations with respect to improvements or changes influenced by their scholarship; for the university in terms of awareness of the potential of innovative online programs, provision of adequate technical and human resources, enhancement of doctoral mentoring skills and faculty professional development.

I recommend this book to anyone developing new online university programs at the graduate level. It may be useful in several other contexts as well. The value of the model proposed is not limited to the United States, nor to the discipline of Education. There is practical advice for those undergoing program evaluation or revision subsequent to formal reviews or other curriculum changes. The design, implementation and evaluation guidelines describe good practice for any graduate program development initiative, including on campus and blended, given the ubiquity of online educational delivery. The model also has the potential to inform university-wide conversations about rethinking the $\mathrm{PhD}$ and redesigning the dissertation (CAGS, 2018). The EdD ETEC case offers scope and structure for reflection and action on program development from an experienced academic practitioner perspective. Published by Athabasca University Press, and one of 13 books in the distinguished Series in Distance Education, this book is available for free download (http:// aupress.ca/index.php/books/120272) making it openly accessible to anyone.

\section{References}

Canadian Association for Graduate Studies. (2018, September). Report of the Task Force on the Dissertation: Purpose, content, structure, assessment. [retrieved November 24, 2018 from https://cags.ca/rethinkingphd/].

Garrison, D.R., Anderson, T. \& Archer, W. (2000). Critical inquiry in a text-based environment: Computer conferencing in higher education. The internet and higher education, 2(2/3), 87-105.

Moore, M.G. (1993). Theory of transactional distance. In D. Keegan (Ed.), Theoretical principles of distance education (pp. 22-38). New York and London: Routledge.

Shea, P. \& Bidjerano, T. (2010). Learning presences as a moderator in the community of inquiry model. Computers and Education, 59(1), 316-326. 